Historic, Archive Document

Do not assume content reflects current scientific knowledge, policies, or practices. 



\section{The Cottage Gardens}

Lansing, Jichigan

\section{SUPPLEMENT TO 1926 HARDY PLANT CATALOG}

Some rare and interesting Perennials not listed in our 1926 Catalog.

SHIPMENT CAN BE MADE SEPTEMBER, OCTOBER OR SPRING

ACONITUM NAPELLUS (True Monkshood or He'met Flower), 3-4 feat, blooms July-August.

The best known Aconitum. This plant thrives in either sun or shade. The roots are poisonous and should not be planted where the tubers might be mistaken for vegetables. The flowers are of a wonderful dark blue shade

ADENOPHORA Liliifolia, a campanula-like border perennial, blue flowers, nodding, on short pedicels, produced freely in midsummer in slender but stiff, erect panicles or loose racemes. Culture same as Campanula

AGROSTEMMA HYBRIDA Walkeri, a leautiful hybrid of A. Coronaria. Iarge heads of deep rosy-red flowers

ALYSSUM SAXATILE fl. pl. compacta, (Rock Madwort), exquisite for the rock garden ...

ANCHUSA, Affinis, dwarf, azure blue. Very pretty

ANCHUSA, Barrelieri, 2 feet, blue flowers with a white tube and pink or yellow throat, least common

CATANANCHE Coerulea (Cupid's Dart), 2 feet. A lovely plant, producing heads of pretty deep lavender-blue flowers on long wiry stems. July and August.

CENTAUREA Rabylonica, attrastive yellow flowers, suitable for large borders or between shrubbery, 6-10 feet, tall stout and striking plant

CENTAUREA Macrocephala, fine border plant, large thistle-like flowers of a golden yellow color, $31 \%$ feet, blooms July and August

CENTRANTHUS Ruber (Red Valeriana), 1-3 feet. A very handsome old garden plant, too much neglected, blooms all summer, flowers deep crimson to pale red..

CHRYSANTHEMUM MAXIMUM, Mrs. C. Lowthian Be!l. This is undoubtedly the largest fowered of all shasta daisies. Flowers sometimes measure 6 inches across with very broad petals of great substance. Pure white, 21/2-3 feet high

DIANTHUS Caesius (Cheddar Pink). This plant grows from 4-10 inches high, very compact in growth and makes a cushion of glaucous leaves which, in May bring forth the sweet smelling rose colored flowers. Excellent for the rock garden

DIANTHUS Dento us Hybrids. A very interesting species, called the "Amoor Pink". Grows one foot high and forms one of the finest border plants. Flowers are large and almost cover the foliage

DIANTHUS Plumarius Mrs. Sinkins, large, clove-scented flowers, in great abundance

DIANTHUS Plumarius Nanus flora plena, dwarf pinks, double mixed

DICTAMNUS (Gasplant), Albus

ECHINACEA (see Rudbeckia Purpurea).

GYPGOPHILA, Acutifolia (Pink Baby's Breath). Very pretty perennial, resembling the copular white Baby's Breath 
GYPSOPHILA Repens. Very pretty trailing plant with clouds of small white and pink flowers in July and August

Each Dozen

IOPSIS Imbricata. A dwarf form of the well-known Heliopsis Scabra. Its flowers are

HELIOPSIS Imbricata. A dwarf form of the well-known Heliopsis Scabra. Its flowers are
golden yel'ow, measuring 3 inches across

HIBIsCUS Militaris, grows 4-6 feet tall, strong growing plant with flowers 3-5 inches across, ranging in white, blush or pale rose with purple eye .25

IRIS Siberica Corea, very pretty blue variety

LINARIA Cymbalaria, rale purple, neat trailing indigenous species

LUPINES, Regal Hybrids, an unusually fine strain of Lupines

LYCHNIS Alpina, a very pretty form, dwarf, beautiful rosy-pink flowers on long stem. Grows one foot tall

LYCHNIS Arkwrightii, magnificent novelty in shades of orange red, $1 \frac{112}{2}$ feet tall, large star-shaped flowers, unusually attractive

MONARDA Festulosa, purple flowers in August, later than the well-known Monarda Didyma. This plant grows well in dry positions

MONARDA Mixed Hybrids, purple shades, very interesting species

NEPETA MACRANTHA, showy border species, abundance of violet flowers, 2 feet

RUDBECKIA Purpurea Grandiflora (Giant Purple Coneflower), an exceptionally fine border plant growing 3 feet high and producing large rosy-purple coneflowers

RUDBECKIA Purpurea Hybrida, beautiful hybrids

RUDBECKIA Hirta, 2 feet, orange with dark eye, all summer

SALVIA Sclarea, blue and white flowers, large wooly foliage, 3 feet high

SPIREA Filipendula, pretty fern-like foliage with numerous corymbs of beautiful white flowers, June and July

VERONICA Spicata Nana, blocms June and July, dwarf form of Spicata, flowers a pretty blue

VIOLA, Cornuta, Admiration, large dark blue

ViolA, Cornuta, Black Prince

VIOLA, Cornuta, Blotched Hybrids 